\title{
EXPERIMENTAL TESTS ON THE INFLUENCE OF WASTE COVERING LAYER ON ODOUR REDUCTION
}

\author{
BADANIA WPEYWU WARSTWY POKRYWAJĄCEJ ODPADY \\ NA REDUKCJĘ ODORU
}

\begin{abstract}
Waste management is one of the most relevant problems of environmental protection. Landfills constitute an unavoidable component of the waste management system. The article discusses the problem of landfill odours. Reduction of waste tipping areas and temporary waste covering are the most efficient measures for reducing odours from landfills. The article presents the results of experimental tests on the use of building debris for the reduction of odours from landfills. Tests were performed by applying dynamic olfactometry. Upon covering waste with the building debris layer of $10 \mathrm{~cm}$ thickness odour thresholds fell from 51.0 to $79.7 \%$ compared with uncovered waste.
\end{abstract}

Keywords: landfill odours, waste cover, building debris, dynamic olfactometry

\section{Introduction}

Waste generation is an unavoidable result of economic activities. It has been determined that industry production increases by 10 times every 25 years. A mere $2 \%$ of used resources become products, while all the rest of them are waste. Consequently, waste handling is one of the most relevant problems of environmental protection.

Waste disposal in landfills results in the formation of methane $\left(\mathrm{CH}_{4}\right)$, volatile organic compounds (VOC), odours and leachate, the spread of the infection through insects, rodents and birds, and the threat of explosions [1]. The problem of odours is particularly relevant. Odorous compounds generating in landfills are normally felt in the presence of very low concentrations.

The following main sources of odours in landfills were identified [2]:

- the places of waste discharge in which waste is tipped out of trucks, spread and compacted;

- $\quad$ operable sections of landfills in which odours are emitted from temporarily covered waste;

\footnotetext{
${ }^{1}$ Institute of Environmental Protection, Vilnius Gediminas Technical University, Sauletekio al. 11, LT-10223 Vilnius, Lithuania, phone +370 52744726

*Corresponding author: sauliusv@vgtu.lt
} 
- closed sections of landfills in which odour generation is determined by the tightness of cover layers and efficiency of a gas collection system;

- the landfill gas collection system, landfill's section not connected to the system;

- the landfill leachate collection system.

Table 1

Composition of odours from the landfill [3]

\begin{tabular}{|c|c|c|c|c|c|}
\hline Landfill & $\begin{array}{c}\text { Percentage } \\
\text { odour } \\
\text { contribution }\end{array}$ & Waste tipping area & $\begin{array}{c}\text { Percentage } \\
\text { odour } \\
\text { contribution }\end{array}$ & $\begin{array}{c}\text { Landfill gas } \\
\text { system }\end{array}$ & $\begin{array}{c}\text { Percentage } \\
\text { odour } \\
\text { contribution }\end{array}$ \\
\hline Ethylbenzene & 24.3 & 2,3-butanedione & 31.6 & Ethylbenzene & 40.8 \\
\hline 2,3-butanedione & 21.6 & Methyl-mercaptan & 24.7 & Methyl-mercaptan & 20.5 \\
\hline Methyl-mercaptan & 20.0 & Hydrogen sulphide & 22.5 & $\begin{array}{c}\text { Hydrogen } \\
\text { sulphide }\end{array}$ & 18.9 \\
\hline Hydrogen sulphide & 18.5 & Ethylbenzene & 11.3 & Dimethyl-sulphide & 7.5 \\
\hline Dimethyl-sulphide & 5.3 & Dimethyl-sulphide & 3.4 & Sulphur dioxide & 4.7 \\
\hline Sulphur dioxide & 2.0 & 2-methylpropanal & 1.2 & Carbon disulphide & 2.8 \\
\hline $\begin{array}{c}\text { Dimethyl- } \\
\text { disulphide }\end{array}$ & 1.9 & i-propyl-mercaptan & 1.2 & Benzene & 1.8 \\
\hline Carbon disulphide & 1.8 & Dimethyl-disulphide & 0.7 & 2,3-butanedione & 0.6 \\
\hline Benzene & 0.8 & Ethylmercaptan & 0.7 & m,p-xylenes & 0.6 \\
\hline i-propyl-mercaptan & 0.6 & Ethanol & 0.5 & 2-methylpentane & 0.3 \\
\hline
\end{tabular}

Table 1 shows the percentage composition of odours emitted from the landfill, waste tipping sites and the landfill gas collection system. Specific odour emissions from separate sections of an operating landfill are shown in Figure 1.

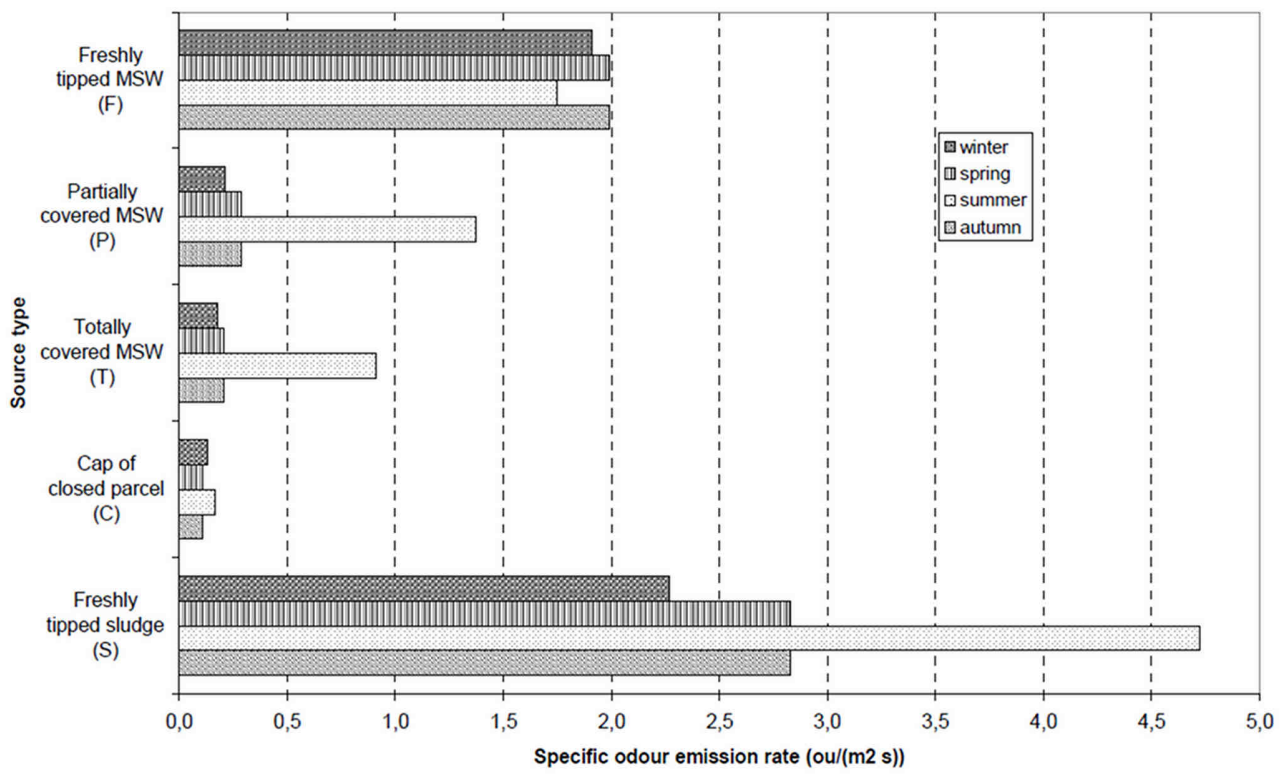

Fig. 1. Odour emissions from individual parts of the landfill [4] 
The highest specific odour emissions are from freshly tipped sewage sludge [4]. Odours get fainter while passing from $\mathrm{F}$ (freshly discharged municipal waste) to $\mathrm{T}$ (totally covered waste). Odour formation in the sources $\mathrm{F}$ (freshly disposed municipal waste) and $\mathrm{C}$ (closed landfill section) is hardly dependent on the season of the year. The highest odour emissions from the sources $\mathrm{P}$ (provisionally covered waste), $\mathrm{T}$ and $\mathrm{S}$ were identified in summer, while the lowest - in winter.

Taking into account the season of the year, the concentration of monoaromatic hydrocarbons varies between 0.09 and $47.42 \mu \mathrm{g} / \mathrm{m}^{3}$, that of halogenated compounds - from 0.001 to $62.91 \mu \mathrm{g} / \mathrm{m}^{3}$, aldehydes - from 0.01 to $38.55 \mu \mathrm{g} / \mathrm{m}^{3}$, esters - from 0.01 to $7.54 \mu \mathrm{g} / \mathrm{m}^{3}$, ketones - from 0.03 to $7.60 \mu \mathrm{g} / \mathrm{m}^{3}$, sulphur and nitric compounds - from 0.03 to $5.05 \mu \mathrm{g} / \mathrm{m}^{3}$, volatile fatty acids - from 0.05 to $43.71 \mu \mathrm{g} / \mathrm{m}^{3}$ [5].

The amount of hydrogen sulphide $\left(\mathrm{H}_{2} \mathrm{~S}\right)$ in the Jerubaiciai landfill of Telsiai region varies from $0.9 \mathrm{ppm}$ in February to $8.6 \mathrm{ppm}$ in August [6]. The highest amounts of hydrogen sulphide were identified in waste tipping places. $\mathrm{H}_{2} \mathrm{~S}$ formation is influenced by aerobic and anaerobic conditions [7]. The main factor responsible for $\mathrm{H}_{2} \mathrm{~S}$ formation is air temperature.

Reduction of waste tipping areas and provisional waste covering are the most efficient measures for the reduction of odours from landfills [2]. It has been determined that the capacity of compost to adsorb hydrogen sulphide increases when the size of particles and acidity decrease and the content of humidity increases [8]. The optimum adsorption of $\mathrm{H}_{2} \mathrm{~S}$ is achieved by the compost with the size of particles below $4 \mathrm{~mm}$, natural $\mathrm{pH}$ and $40 \%$ humidity content.

Emissions of the hydrogen sulphide whose odour threshold equals $0.012-0.03 \mathrm{mg} / \mathrm{m}^{3}$ are reduced with the help of crushed wood bark [9]. $\mathrm{H}_{2} \mathrm{~S}$ emissions from compost mixed with bark are lower than those from compost covered with bark.

When waste is covered with compost having $590 \mathrm{~kg} / \mathrm{m}^{3}$ bulk density, landfill odours are reduced by $69 \%$ [10]. When the bulk density of compost is $740 \mathrm{~kg} / \mathrm{m}^{3}$, odour emissions fall by $97 \%$. Effective removal of volatile organic compounds is achieved upon using a mixture of green (garden) waste compost and wood sawdust [11].

Where biodegradable waste is layered using expanded clay, methane emissions are lower compared with pure waste [12]. Where expanded clay is layered with waste, the amount of oxygen decreases slowly and the concentrations of generating methane fall due to air spaces.

Ashes of different fractions, glass breakage or sewage sludge can be used in the systems for landfill cover [13]. As proved by tests, a $200 \mathrm{~mm}$ layer of constructiondemolition dust and wood sawdust is effective in respect of odour reduction [14].

Control of landfill odours is a relevant problem and its addressing requires precise and representative assessment techniques [15]. In Lithuania, from 2010 the amount of biodegradable municipal waste going to landfills must be reduced to $75 \%$, from $2013-50 \%$ and from 2020 - 35\% of the total amount produced in 2000 [16]. The use of efficient materials for periodic waste covering would not only reduce the effect of adverse factors on the environment but would also help to more efficiently deal with the problem of quick completion of the landfill site. The aim of this research is to evaluate the possibilities of using building debris for the reduction of odours in municipal landfills. 


\section{Research methods}

During the experiment mixed kitchen waste was placed into a $1.0 \mathrm{~m}^{3}$ capacity box and covered with a layer of building debris (Fig. 2). The box was lined with low density polyethylene film, $0.15 \mathrm{~mm}$ thick. In order to prevent waste and building debris from being mixed up, a $350 \mathrm{~mm}$ layer of compacted waste was covered with $17 \mathrm{~g} / \mathrm{m}^{2}$ agri film.

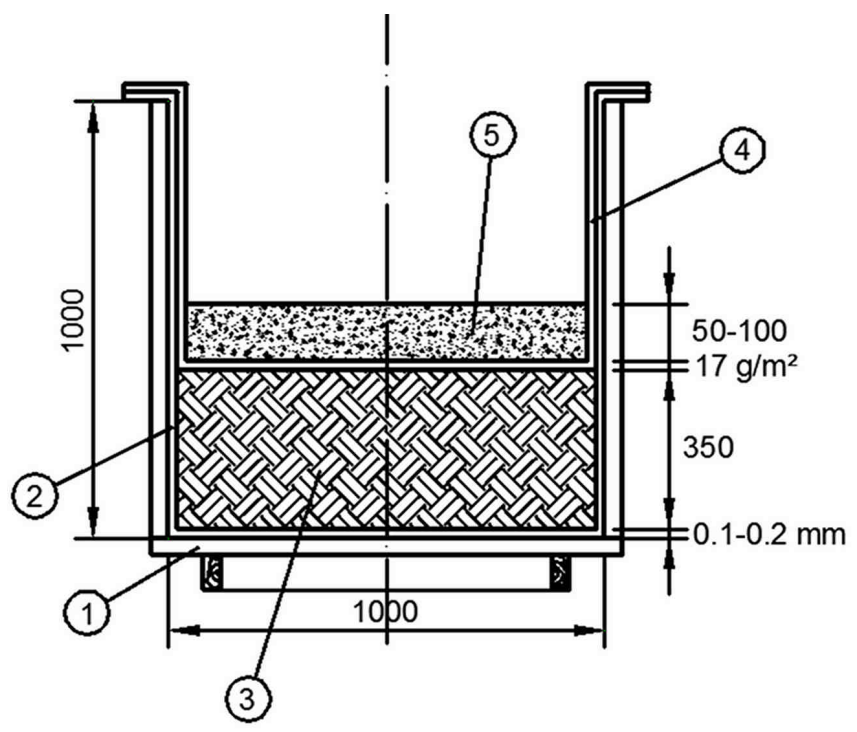

Fig. 2. Experimental display: 1 - wooden box, 2 - $0.15 \mathrm{~mm}$ polyethylene film of low density, 3 - biodegradable waste, $4-17 \mathrm{~g} / \mathrm{m}^{2}$ agri film, 5 - building debris

A granulometric composition of the building debris (crushed concrete and brickwork) used for waste covering is presented in Figure 3. In accordance with partial residues on sieves the main fractions of building debris are $1-4 \mathrm{~mm}(22.5 \%)$ and $4-10 \mathrm{~mm}(30.7 \%)$. Debris' bulk density $-1.32 \mathrm{~g} / \mathrm{cm}^{3}$, humidity content $-1.7 \%$.

Mixed kitchen waste was selected as the source of odours. It accounts for $14 \%$ of the total municipal waste amount [17]. The processes of biodegradable waste degradation predetermine the formation of odours [18]. The waste used for the tests had $0.48 \mathrm{~g} / \mathrm{cm}^{3}$ density, $74.8 \%$ humidity content and $34.6 \%$ total organic carbon (TOC) content. The total organic carbon content was established with the Shimadzu instrument TOC-VCSN.

With the aim of avoiding the influence of precipitation and the formation of leachate, testing was performed in indoors. The testing comprised two stages. In the first stage odour samples were taken every second day from uncovered waste, a $5 \mathrm{~cm}$ thick layer of building debris and a $10 \mathrm{~cm}$ thick layer of building debris. In the second stage samples were taken every day from uncovered waste (1 day), a $5 \mathrm{~cm}$ thick layer of building debris (3 days) and a $10 \mathrm{~cm}$ thick layer of building debris (3 days).

Odour samples were taken in the second half of the day (after 12:00). Upon taking the first sample, air temperature and relative humidity in the room were measured with the multifunctional meter for measuring air parameters METREL MI6401. The instrument's 
ambient temperature measurement range is $-20-60^{\circ} \mathrm{C}$, resolution $0.1^{\circ} \mathrm{C}$, accuracy $\pm 0.5^{\circ} \mathrm{C}$ $\left( \pm 0.2^{\circ} \mathrm{C}\right.$ at $\left.25^{\circ} \mathrm{C}\right)$. Relative humidity measurement range $0-100 \%$, resolution $0.1 \%$, accuracy $\pm 3 \%$ (0-10\%), $\pm 2 \%$ (10-90\%), $\pm 3 \%$ (90-100\%). The second sample was taken after one hour. Samples were taken at a height of several centimetres from the waste or building debris surface with the vacuum chamber AC'SCENT and collected to Tedlar bags of $10 \mathrm{dm}^{3}$ capacity and analysed in a laboratory on the same day [19].

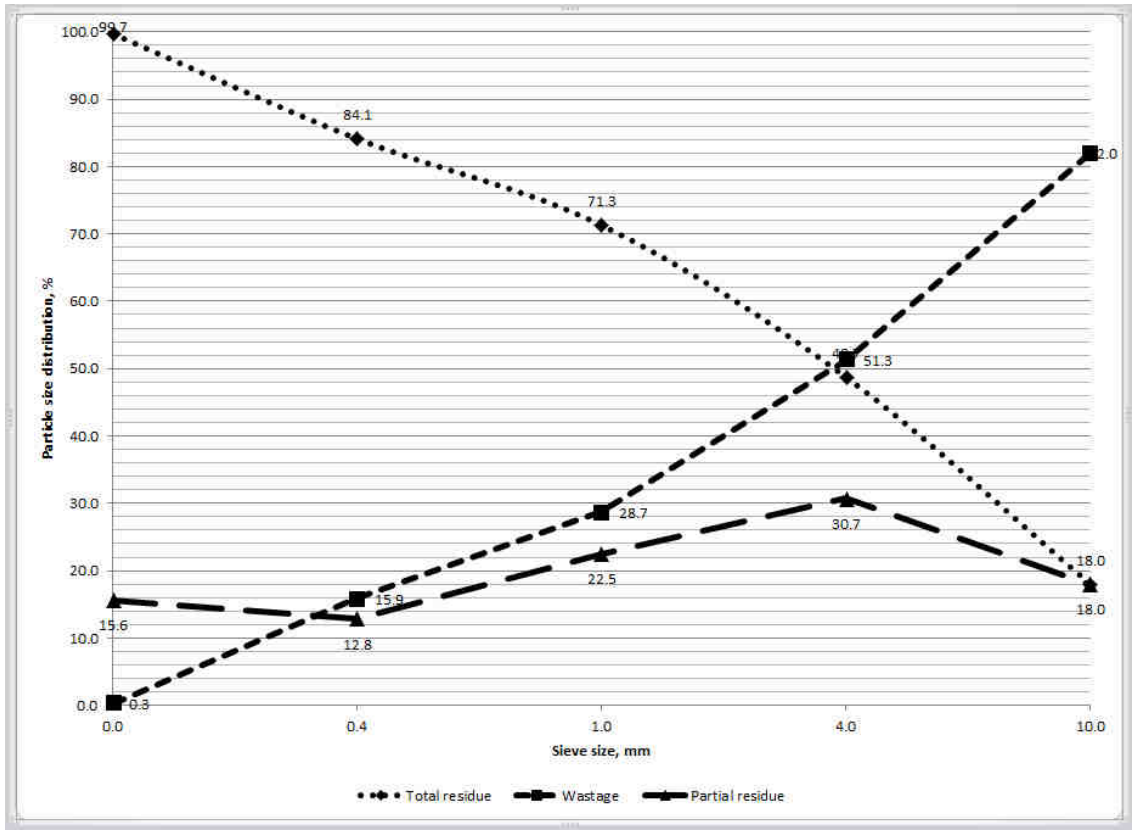

Fig. 3. Building debris granulometric composition curve

Odour samples were analysed with the dynamic olfactometer AC'SCENT complying with the requirements laid down in the EU air quality standard EN 13725:2003 (Determination of odour concentration by dynamic olfactometry).

The analysis was performed by the method of forced selection. A researcher evaluates three deliveries of each dilution. One of them contains the diluted sample at issue, others clean air. The researcher selects guess (one of the deliveries may contain an odour samples), sense (odour is sensed in one of the deliveries) and recognition (the nature of odour is recognised in one of the deliveries) answers. The levels of dilution differ from each other by a two-fold lower dilution ratio and a two-fold higher odour concentration. Each sample is evaluated by 4 researchers.

\section{Research results}

Assessment in the first stage covered the influence of thickness of a building debris layer on the formation of odours (Figs. 4 and 5). In the event of uncovered waste, the highest odour detection thresholds reached 419 and 347 odour units. 


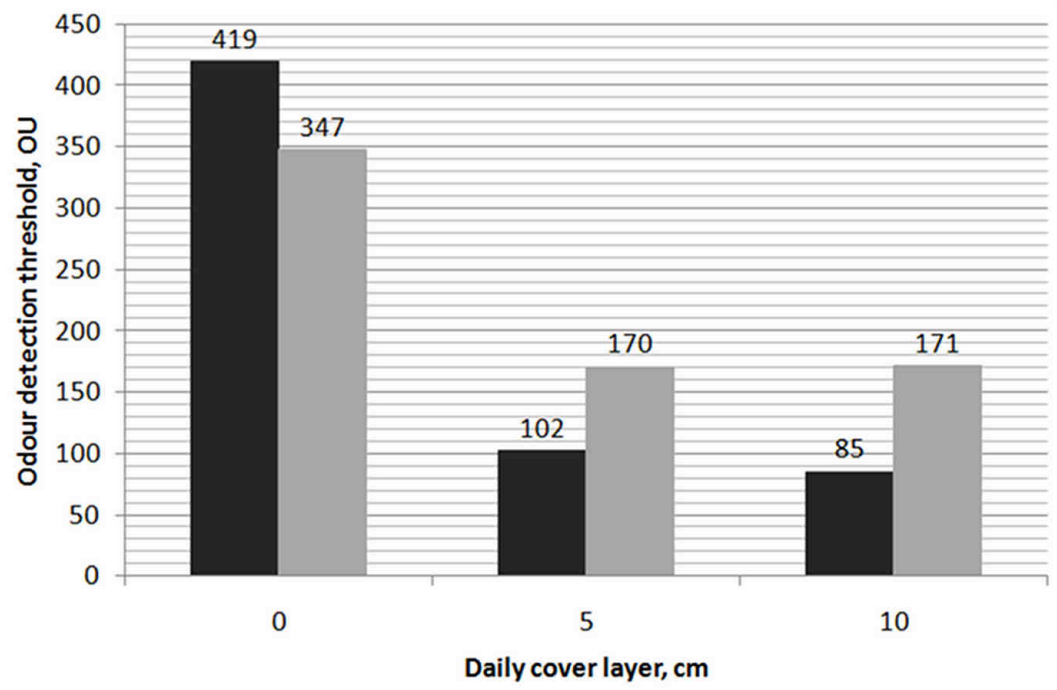

口 Sample No.1 Sample No. 2

Fig. 4. Dependence of odour detection threshold on thickness of a building debris layer

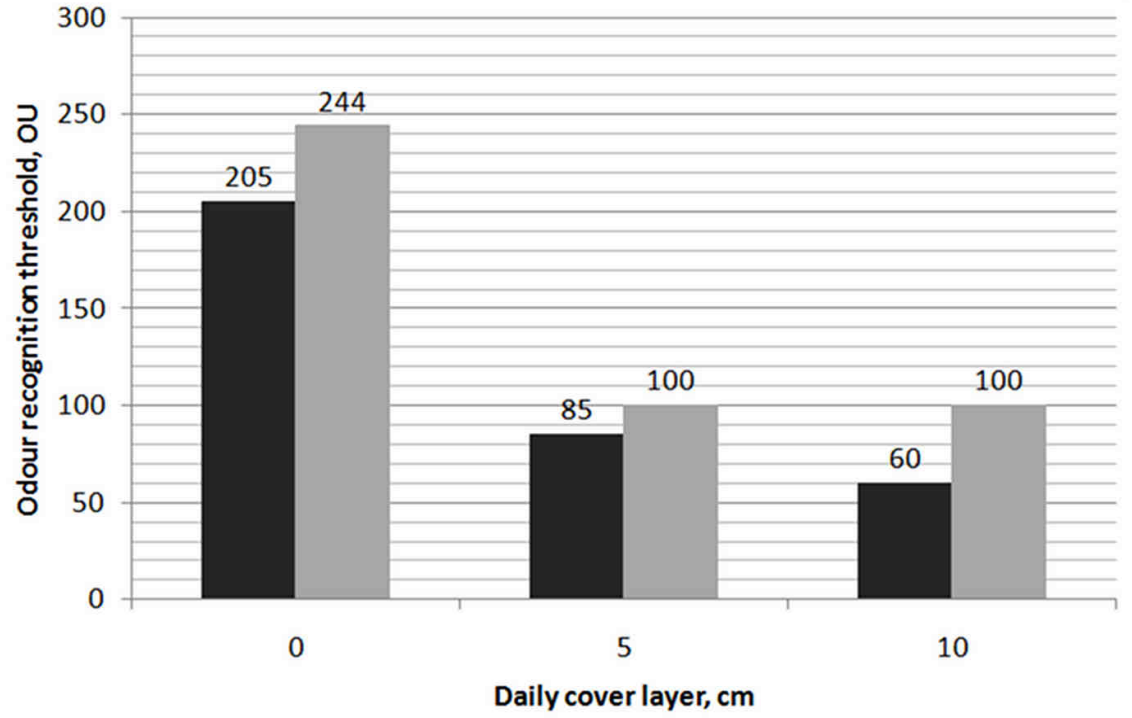

Sample No.1 Sample No. 2

Fig. 5. Dependence of odour recognition threshold on thickness of a building debris layer

Upon covering waste with a building debris layer of the thickness of $5 \mathrm{~cm}$, the odour detection threshold fell by $75.7 \%$ to $102 \mathrm{OU}$ (the first samples) and by $51.0 \%$ to $170 \mathrm{OU}$ (samples after one hour). Upon covering waste with a building debris layer of the thickness 
of $10 \mathrm{~cm}$, the odour detection threshold decreased by $79.7 \%$ to 85 OU compared with uncovered waste and by $16.7 \%$ compared with $5 \mathrm{~cm}$ thick layer (the first samples). The odour detection threshold of the second samples remained unchanged.

The dependence of odour recognition thresholds on the thickness of a building debris layer is similar to that of the odour detection threshold but the values themselves are lower. In the case of uncovered waste the highest odour recognition thresholds reached 205 and 244 odour units.

Upon covering waste with a building debris layer of the thickness of $5 \mathrm{~cm}$, the odour recognition threshold decreased by $58.5 \%$ to $85 \mathrm{OU}$ (the first samples) and by $59.0 \%$ to $100 \mathrm{OU}$ (samples after one hour). Upon covering waste with a building debris layer of the thickness of $10 \mathrm{~cm}$, the odour recognition threshold decreased by $70.7 \%$ to $60 \mathrm{OU}$ compared with uncovered waste and by $29.4 \%$ compared to $5 \mathrm{~cm}$ thick layer (the first samples).

The specific odour emissions from the first samples determined during tests reached $1.26 \mathrm{OU} / \mathrm{m}^{2} / \mathrm{s}$ in the case of uncovered waste, $0.31 \mathrm{OU} / \mathrm{m}^{2} / \mathrm{s}$ in the case of the layer $5 \mathrm{~cm}$ thick and $0.26 \mathrm{OU} / \mathrm{m}^{2} / \mathrm{s}$ in the case of the layer $10 \mathrm{~cm}$ thick. The specific odour emissions of the second samples reached $1.04 \mathrm{OU} / \mathrm{m}^{2} / \mathrm{s}$ in the case of uncovered waste, and $0.51 \mathrm{OU} / \mathrm{m}^{2} \cdot \mathrm{s}$ in the cases of the layer 5 and $10 \mathrm{~cm}$ thick.

In accordance with [4], the specific odour emissions of uncovered waste vary from $1.7 \mathrm{OU} / \mathrm{m}^{2} / \mathrm{s}$ (in summer) to $2.0 \mathrm{OU} / \mathrm{m}^{2} \cdot \mathrm{s}$ (in autumn). The specific odour emissions of covered waste vary from $0.2 \mathrm{OU} / \mathrm{m}^{2} \cdot \mathrm{s}$ (in winter) to $1.4 \mathrm{OU} / \mathrm{m}^{2} \cdot \mathrm{s}$ (in summer). In accordance with [20], the average specific odour emissions in Italian landfills reach $5.5 \pm 3.4 \mathrm{OU} / \mathrm{m}^{2} \cdot \mathrm{s}$. As the tests performed by Odotech Inc. in Canadian municipal waste landfills in 2001 show, odour concentrations in old sections amount to $2.6 \mathrm{OU} / \mathrm{m}^{2} / \mathrm{s}$, in waste tipping sites $-5.4 \mathrm{OU} / \mathrm{m}^{2} \cdot \mathrm{s}$, and $3.5 \mathrm{OU} / \mathrm{m}^{2} \cdot \mathrm{s}$ - in truck parking areas [15].

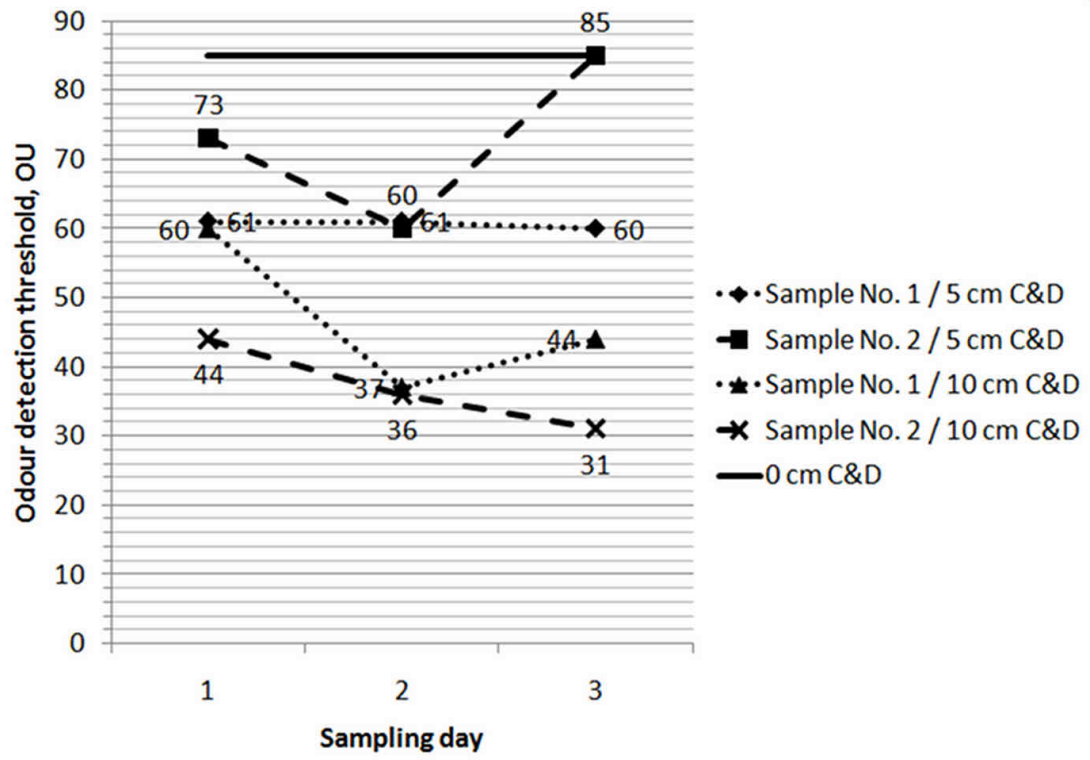

Fig. 6. Dependence of the odour detection threshold on the thickness of a building debris layer vs time 
In accordance with [21], the average concentration of municipal waste landfill odours reaches $1.375 \mathrm{OU} / \mathrm{m}^{2} \cdot \mathrm{s}$. The average odour concentrations presented by [3] vary from 0.3 to $0.5 \mathrm{OU} / \mathrm{m}^{2} \cdot \mathrm{s}$. Odour emissions from landfills normally depend on [4]:

- $\quad$ waste characteristics;

- frequency of waste covering;

- $\quad$ area of waste tipping sites;

- the quantity of waste per time unit;

- meteorological conditions (wind speed, solar radiation, air temperature, relative humidity).

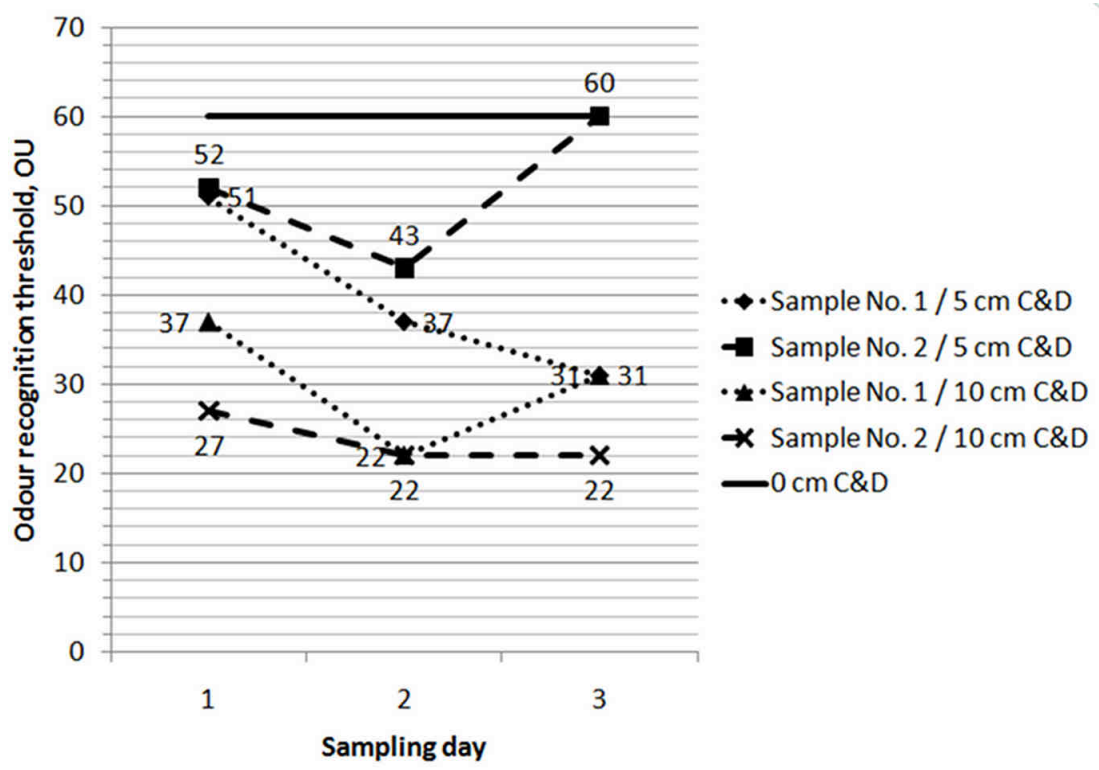

Fig. 7. Dependence of the odour recognition threshold on the thickness of a building debris layer vs time

Assessment in the second stage covered the influence of thickness of a building debris layer on the formation of odours in the course of time (Figs. 6 and 7). The ambient air temperature and relative humidity were also determined (Fig. 8).

In the first samples the highest values of the odour detection threshold were recorded in the case of uncovered waste ( $85 \mathrm{OU}$ ). Upon covering waste with a building debris layer of the thickness of $5 \mathrm{~cm}$, the odour detection threshold fell by $29.4 \%$ to $60 \mathrm{OU}$ and remained stable for all three days. Upon covering waste with a building debris layer of the thickness of $10 \mathrm{~cm}$, the odour detection threshold decreased from $60 \mathrm{OU}$ to $37 \mathrm{OU}(38.3 \%)$ on the second day. On the third day the odour detection threshold reached 44 OU. The total decrease in the odour detection threshold within the testing period (7 days) is $48.2 \%$.

The highest values of the odour detection threshold in the second samples stood at $73 \mathrm{OU}$ (on the first day in the case of the layer $5 \mathrm{~cm}$ thick and $85 \mathrm{OU}$ (on the third day in the case of the layer $5 \mathrm{~cm}$ thick). The total decrease in the odour detection threshold 
accounts for $63.5 \%$. The dependence of odour recognition thresholds on the building debris layer thickness vs time is similar.

When municipal waste is periodically covered with compost the concentrations of landfill odours decrease from 69 to $97 \%$ [10]. Odour concentrations in waste tipping places reaching $4000-30000 \mathrm{OU} / \mathrm{m}^{2} \cdot \mathrm{h}$ decrease to $120-900 \mathrm{OU} / \mathrm{m}^{2} \cdot \mathrm{h}$. In order to reduce gaseous emissions, biodegradable waste is composted with wood sawdust, green (garden) waste, or peat [22]. However, as these materials are non-homogenous their use is limited.

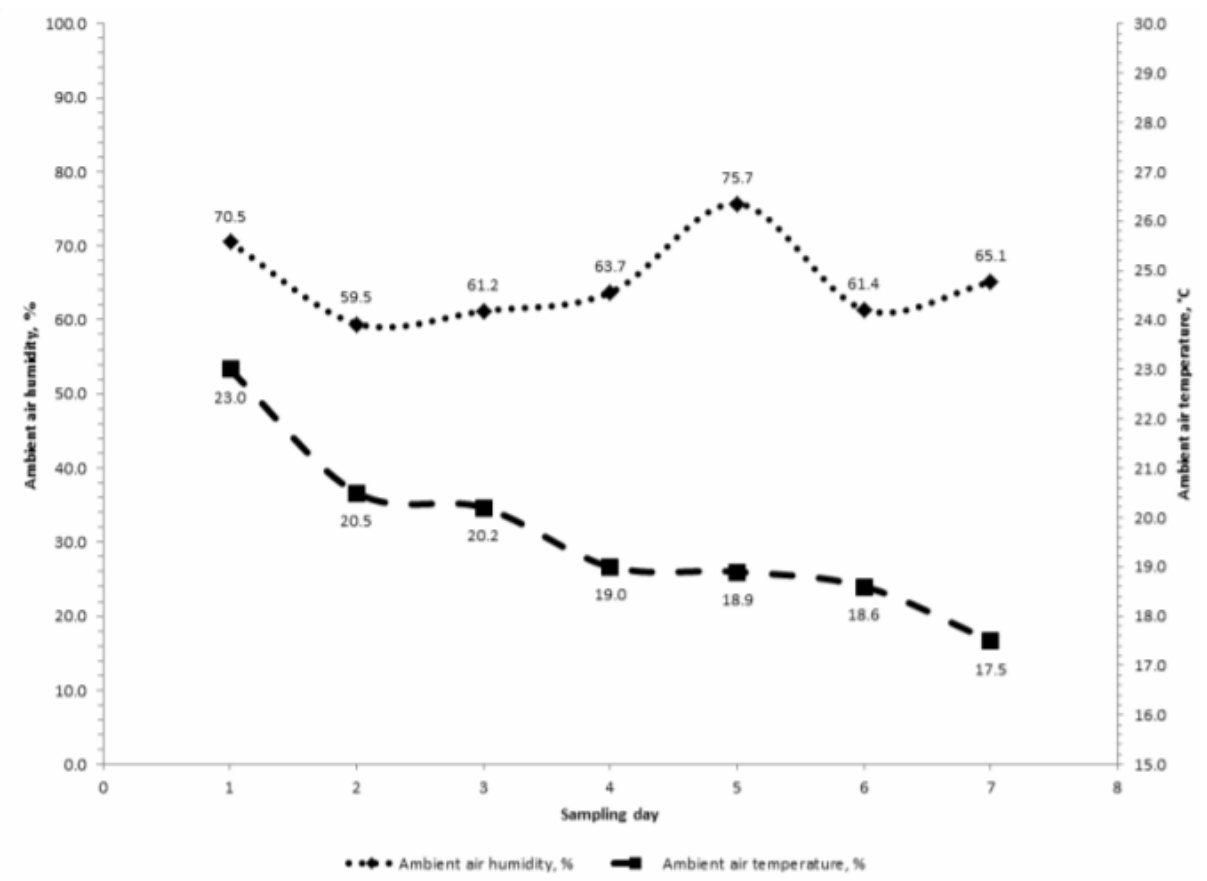

Fig. 8. Alternation of ambient air temperature and relative humidity during the experiment

The odour concentration of the waste covered with a layer consisting of $50 \mathrm{~mm}$ of building debris and $150 \mathrm{~mm}$ of sawdust decreases by more than $50 \%$ [14]. Finely fractioned building debris is distinguished by low concentrations of background odours. This is insignificantly influenced by a waste collection site and methods of treatments.

Where waste is covered with the building debris layer of the thickness of $5 \mathrm{~cm}$ instability of the odour threshold can result from insufficient thickness of the building debris layer. Already on the third day of the testing odour thresholds reached the level of uncovered waste. In the meantime upon covering waste with a $10 \mathrm{~cm}$ thick layer the thresholds gradually decreased or insignificantly fluctuated. In this case fluctuations could have been determined by changes in the relative humidity of the ambient air (Figs. 8 and 9). The correlation coefficient of the odour detection thresholds in the first samples was equal to 0.9988 , that in the second ones - 0.8003. The correlation coefficient of the odour recognition thresholds in the first samples was equal to 0.9262 , that in the second ones 0.9684 . 
Certain fluctuations in the concentrations of background odours resulting from the humidity of materials were determined by [14]. Tests covered wood sawdust, building-demolition and industrial dust. When the content of humidity in materials significantly increases, the specific odour emissions also increase. The increased emission of hydrogen sulphide at a higher humidity of the ambient air was identified by [8]. At higher temperature water vapour pressure grows, which deteriorates the adsorption properties of the filler resulting in more intensive emissions of $\mathrm{H}_{2} \mathrm{~S}$.

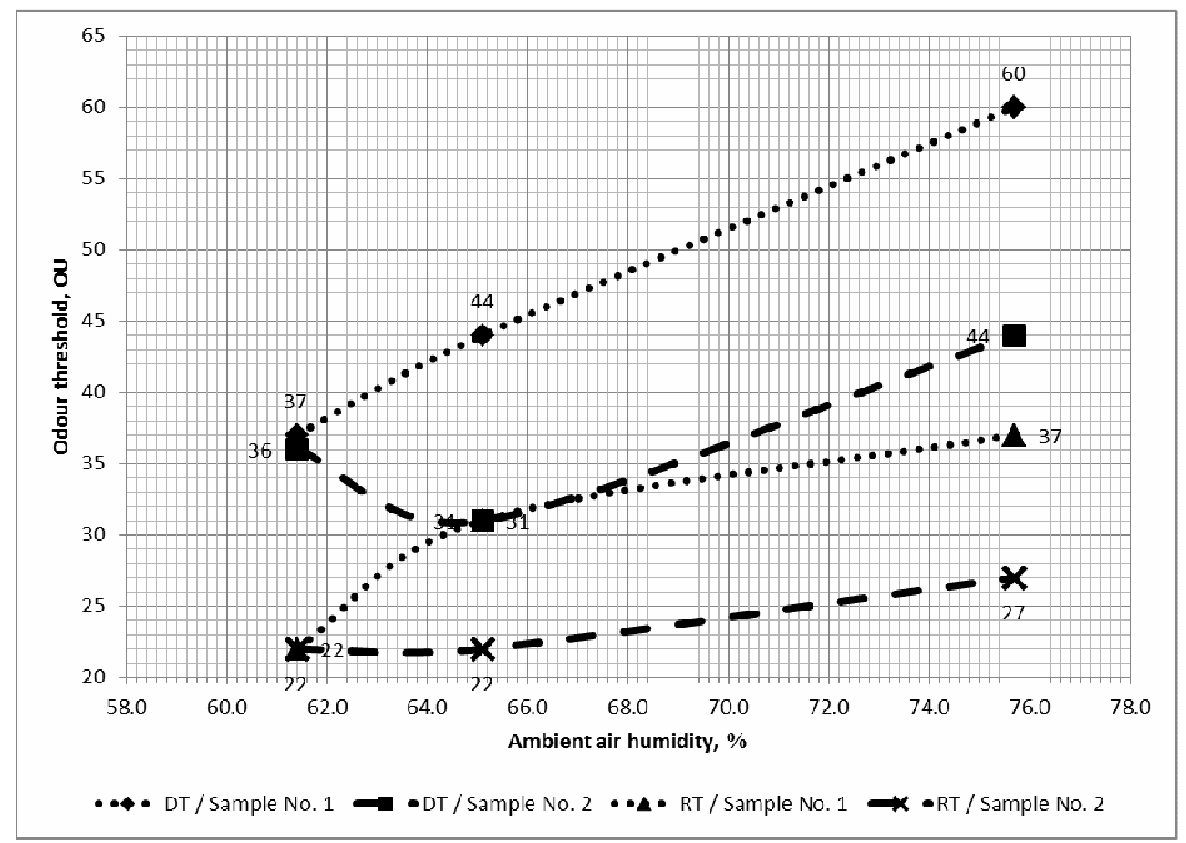

Fig. 9. Dependence of odour thresholds on relative humidity of the ambient air: DT - odour detection threshold, RT - odour recognition threshold

Throughout the testing period (7 days) ambient air temperature was gradually falling. The highest temperature $\left(23.0^{\circ} \mathrm{C}\right)$ was recorded on the experiment's first day when waste was uncovered. The lowest temperature $\left(17.5^{\circ} \mathrm{C}\right)$ was identified on the last day of the test in the case of the building debris layer of $10 \mathrm{~cm}$ thickness (Fig. 8).

On the basis of tests on hydrogen sulphide degradation activity [7], the average value of $\mathrm{H}_{2} \mathrm{~S}$ degradation activity at $28^{\circ} \mathrm{C}$ temperature was by only 1.85 times above the average value at $6^{\circ} \mathrm{C}$ temperature.

During the testing period a difference in temperatures was a mere $5.5^{\circ} \mathrm{C}$ and therefore temperature changes did not have a significant influence on testing results.

\section{Conclusions}

1. Concrete and brickwork building debris could be applied for more efficient reduction of odour emissions from municipal waste landfills. Upon covering waste with the 
building debris layer of $10 \mathrm{~cm}$ thickness, odour thresholds fell from 51.0 to $79.7 \%$ compared with uncovered waste.

2. The specific odour emissions determined during tests $\left(1.04-1.26 \mathrm{OU} / \mathrm{m}^{2} \cdot \mathrm{s}\right.$ in the case of uncovered waste and $0.26-0.51 \mathrm{OU} / \mathrm{m}^{2} \cdot \mathrm{s}$ upon covering waste with building debris) comply with the standard concentrations of odours from municipal waste landfills. Changes in odour intensity result from waste characteristics, landfill operation conditions and environmental parameters.

3. A building debris layer thinner than $10 \mathrm{~cm}$ is insufficient to cover waste for a longer period. Upon covering waste with a $5 \mathrm{~cm}$ layer, instability of odour thresholds was recorded. Already on the third day of the test they reached the level of uncovered waste. In the meantime upon covering with a $10 \mathrm{~cm}$ layer, thresholds were gradually decreasing or varied insignificantly. In this case variations could have been determined by changes in the relative humidity of the ambient air.

\section{References}

[1] Scaglia B, Adani F. Sustainable Landfill and Biological Stability. In: Lavelle JR, editor. Waste Management: Research, Technology and Developments, 2008, 1-35.

[2] Jing-Jing F, Na Y, Dan-Yan C, Li-Ming S, Pin-Jing H. Waste Manage. 2012;32:1401-1410. DOI: http://dx.doi.org/10.1016/j.wasman.2012.02.013.

[3] Devkota RP, Cockfield G, Maraseni TN, Bhattarai R, Devkota B. Environ Res J. 2012;6:182-186. DOI: 10.3923/erj.2012.182.186.

[4] Lianghu S, Youcai Z. Environ Technol. 2013;34:165-172. DOI: 10.1080/09593330.2012.689362.

[5] Dincer F, Odabasi M, Muezzinoglu A. J Chromatogr A. 2006;1112:222-229. DOI: 10.1016/j.chroma.2006.04.075.

[6] Vasarevičius S. J Environ Eng and Landscape Manage. 2011:19:12-20. DOI: 10.3846/16486897.2011.557263.

[7] Taskan E, Hasar H. CLEAN - Soil, Air, Water. 2012;40:487-492. DOI: 10.1002/clen.201100291.

[8] He R, Xia F F, Wang J, Pan CL, Fang CR. J Hazard Mater. 2010;186:773-778. DOI: 10.1016/j.jhazmat.2010.11.062.

[9] Zigmontienè A, Zuokaitė E. J Environ Eng and Landscape Manage. 2010:18:128-136. DOI: 10.3846/jeelm.2010.15.

[10] Hurst C, Longhurst PJ, Pollard SJT, Smith R, Jefferson B, Gronow JR. Environ Pollut. 2005;135:171-177. DOI: http://dx.doi.org/10.1016/j.envpol.2004.09.004.

[11] Font X, Artola A, Sanchez A. Sensors. 2011;11:4043-4059. DOI: 10.3390/s110404043.

[12] Baltrenas P, Jankaite A, Raistenskis E. J Environ Eng and Landscape Manage. 2005:13:167-176. DOI: 10.1080/16486897.2005.9636867.

[13] Herrmann I, Svensson M, Ecke H, Kumpiene J, Maurice C, Andrea L, Lagerkvist A. Water Res. 2009:43;3541-3547. DOI: 10.1016/j.watres.2009.04.052.

[14] Solan PJ, Dodd VA, Curran TP. Bioresour Technol. 2010:101;1115-1119. DOI: 10.1016/j.biortech.2009.09.030.

[15] Nicolas J, Craffe F, Romain AC. Waste Manage. 2006:26; 1259-1269. DOI: 10.1016/j.wasman.2005.10.013.

[16] Misevičius A, Baltrenas P. J Environ Eng and Landscape Manage. 2011:19:167-177. DOI: 10.3846/16486897.2011.576456.

[17] Municipal Solid Waste [2012 05 27]. Internet adress: < http://css.snre.umich.edu/css_doc/CSS04-15.pdf > .

[18] Pichtel J. Waste Manage Practices: Municipal, Hazardous, and Industrial. Boca Raton: Taylor \& Francis Group; 2005.

[19] Brattoli M, Gennaro G, Pinto V, Loiotile AD, Lovascio S, Penza M. Sensors. 2011:11;5290-5322. DOI: 10.3390/s110505290.

[20] Sironi S, Capelli L, Centola P, Rosso R, Grande M. Atmos Environ. 2010;39:5387-5394. DOI: 10.1016/j.atmosenv.2005.05.023. ISSN: 1352-2310.

[21] Chemel C, Riesenmey C, Batton-Hubert M, Vailant H. J Environ Manage. 2012:93;85-94. DOI: 10.1016/j.jenvman.2011.08.016. 
[22] Donovan SM, Pan J, Bateson T, Gronow JR, Voulvoulis N. Waste Manage Res. 2011:29;69-76. DOI: $10.1177 / 0734242 \times 10389510$.

\title{
BADANIA WPLYWU WARSTWY POKRYWAJĄCEJ ODPADY NA REDUKCJE ODORU
}

\begin{abstract}
Abstrakt: Gospodarka odpadami jest jednym z najbardziej istotnych problemów związanych z ochroną środowiska. Składowiska stanowią nieunikniony element systemu gospodarki odpadami. W artykule omówiono problem odorów uwalnianych z takich składowisk. Redukcja powierzchni składowisk i czasowe ich pokrycie są najbardziej efektywnymi środkami zmniejszenia emisji odorów. W artykule przedstawiono wyniki badań eksperymentalnych dotyczących wykorzystania gruzu budowlanego do redukcji nieprzyjemnych zapachów ze składowisk. Badania przeprowadzono przy zastosowaniu olfaktometrii dynamicznej. Po pokryciu odpadów warstwą gruzu budowlanego o grubości $10 \mathrm{~cm}$ próg zapachu spadł z 51,0 do 79,7\% w porównaniu z odpadami odkrytymi.
\end{abstract}

Słowa kluczowe: odory ze składowiska, pokrywanie odpadów, gruz budowlany, olfaktometria dynamiczna 